\title{
Hard to Monopolize Kopi Luwak
}

Kopi Luwak is the rare coffee from Indonesia and has a distinctive taste, a bit of earthiness and chocolate flavor and also tastes less bitter than the other coffee beans around the world (Pratono, 2012). The distinctive flavor it is because the coffee bean are fermented using Luwak a species of civets that eats coffee beans, The Luwak civets only eats the ripest coffee beans out in the area than coffee luwak come from the Luwak's feces that has been fermented because the luwak can't digest the beans so the enzyme assimilate with the beans ( Pratono, 2012). Due the hard and complicated process of making these coffee beans the price of the coffee are ridiculously expensive around $\$ 300 /$ cup, this means that the coffee can make a huge significant impact in Indonesia exports.

The problem is the Kopi Luwak only produces by small firms this make a completion with other just like the Turkish electricity competition. The reason of the competition is the different quality and the sustainability of producing the product (Özbuğday, 2016), this make kopi Luwak competition very stiff because sustainability of producing Luwak is very hard because Producers cant cage the Luwak and feed them it will make a low quality of the product because Luwak can't find the ripest coffee and the cage make the Luwak stress, the other problem with sustainability of the product is the Luwak is hard to breed because the male Luwak eat their baby and only the male Luwak produces the finest quality of the coffee ( Pratono, 2012)

The PTP XII the largest Kopi Luwak industries in Indonesia but this company still under competition because monopoly is happened when there is only one who sell the product in the market (Capen, 1978), the company also can't make a huge significant price different with other seller because the price of the product is already high. The other problem if the company wants to monopoly is they can't set the price because there is no big significant difference quality with other firms, the problem is smaller firm also can produces the same quality of the product but not the quantity of the product, as we know human nature is to find the cheapest product for the highest satisfaction and we also know smaller firms can make the product price lower because the lower the expenses of processing the product so it's hard to set the price in the Kopi Luwak market.

\section{Bibliography}

Pratono, R. (2012). Kopy Luwak: a conservation strategy. Emerald Emerging Markets Case Studies, 1.

Capen, M. (1978). MONOPOLY AND PUBLIC POLICY IN SIXTEENTH AND SEVENTEENTH CENTURY GREAT BRITAIN. Emerald Studies in Economics and Finance, 2-6.

Özbuğday, Ö. A. (2016). The sustainability of Turkish electricity distributors and last-resort electricity suppliers: What did transition from vertically integrated public monopoly to regulated competition with privatized and unbundled firms bring about? elsevier utility policies volume 39 , 1-4. 